\title{
Karakteristik Seting Fisik Ruang Interaksi Warga di Kampung Bantaran Sungai Winongo Yogyakarta
}

\author{
Sidhi Pramudito \\ Program Studi Arsitektur, Fakultas Teknik, Universitas Atma Jaya Yogyakarta \\ sidhi.pramudito@uajy.ac.id
}

\begin{abstract}
ABSTRAK
Kampung merupakan salah satu bentuk ruang bermukim di kota dengan karakteristik yang khas. Yogyakarta merupakan salah satu kota di Indonesia yang masih memiliki kampung sebagai bagian dari ruang bermukim warganya, salah satunya adalah kampung yang terletak di bantaran sungai. Adanya bantaran sungai membentuk kondisi seting fisik yang unik pada kampung tersebut. Hal tersebut secara tidak langsung berpengaruh pada terciptanya ruang interaksi antar warga. Keunikan dan keterbatasan ruang tersebut menjadi menarik untuk diamati lebih lanjut sebagai dasar pemahaman kearifan lokal dalam perencanaan ruang kampung di masa depan. Penelitian ini menggunakan metode eksploratif, yang dilakukan dengan observasi lapangan untuk mengumpulkan data dengan studi kasus pada Kampung Gampingan di bantaran Sungai Winongo. Tujuan dari penelitian ini untuk mengidentifikasi variasi seting fisik ruang yang digunakan warga untuk melakukan interaksi di kampung bantaran sungai. Hasil dari penelitian ini ditemukan beberapa karakteristik seting fisik kampung yang mempengaruhi warga dalam melakukan interaksi yaitu kombinasi pelingkup dan elemen pengisi ruang untuk berbagai variasi kegiatan warga. Hasil tersebut diharapkan dapat digunakan sebagai referensi dalam melakukan penataan Kampung Gampingan sebagai salah satu kawasan kumuh di kota Yogyakarta di masa mendatang yang akomodatif terhadap karakteristik seting ruang interaksi warganya.
\end{abstract}

Kata kunci: seting fisik, ruang interaksi, kampung, bantaran sungai Winongo

\begin{abstract}
Kampung is one type of living space in a city with distinctive characteristics. Yogyakarta is one of the cities in Indonesia which still has a village as part of its inhabitant' living space, one of them is a riverbank kampung. The existence of a riverbank creates a unique physical setting in the kampung, which indirectly affects the creation of inhabitant interaction space. The uniqueness and limitations of the space become interesting to be observed further as a basis for understanding local wisdom in planning future village spaces. This study uses an exploratory method, which was carried out by field observations to collect data with case studies in Kampung Gampingan on Winongo riverbank. This study aimed to determine the variations in the physical settings of space used by residents to interact in the riverbank kampung. The results of this study found several characteristics of physical settings of kampung that affect citizens in conducting interactions, as the combination of the enclosure and spatial elements for a variety of community activities. These results are expected to be used as a reference in conducting the arrangement of Kampung Gampingan as one of the slums in the city of Yogyakarta in the future that is accommodating to the characteristics of the setting of interaction spaces of its citizens.
\end{abstract}

Keywords: physical settings, interaction space, kampung, Winongo riverbank 


\section{Pendahuluan}

Kampung merupakan salah satu bentuk ruang bermukim di kota Indonesia. Istilah kampung dipakai untuk menjelaskan fenomena perumahan di perkotaan yang dibangun secara swadaya atau mandiri oleh para migran dari pedesaan. Beberapa ahli menyebut bentuk ruang bermukim tersebut dengan istilah kampung kota, yaitu perumahan seperti kampung pedesaan namun berada di kota yang kemudian sering disebut sebagai kampung kota (Setiawan, 2010). Di dalam kampung kota terdapat penghuni dengan berbagai latar belakang status sosial dan ekonomi yang dapat bertahan hidup di tengah kemajuan kota yan pesat. Dalam situasi krisis yang tidak menguntungkan, keberadaan kampung kota menjadi penting karena di dalamnya terdapat beragam proses unik yang dilakukan oleh penghuni berpenghasilan menengah ke bawah khususnya dalam hal pemanfaatan lahan (Kusyala, 2008) dalam (Tamariska, 2017).

Kondisi kampung yang khas tentunya akan mempengaruhi tata cara kehidupan masyarakatnya, salah satunya adalah cara warga berinteraksi. Sebagai makhluk sosial manusia memiliki dorongan untuk berinteraksi sosial dengan orang lain dan memiliki kebutuhan sosial untuk hidup berkelompok dengan orang lain (Sharma, 2012). Interaksi sosial merupakan hubungan-hubungan yang dinamis menyangkut hubungan antar orang, antar kelompok, maupun antar individu dengan kelompok manusia (Yuliastuti, 2011).

Dalam lingkungan kampung interkasi sosial dapat terjadi dimana saja baik di ruang-ruang formal maupun maupun ruang informal. Kondisi kampung dengan segala kelebihan dan kekurangannya merupakan suatu karakteristik tersendiri bagi sebuah sistem kawasan. Kampung umumnya tidak didukung oleh sarana dan prasarana yang memadai. Ruang terbuka publik sebagai ruang interaksi juga merupakan masalah yang menonjol di kampung. Tuntutan ekonomi yang semakin besar menyebabkan penduduk kampung semakin melihat ruang sebagai komoditas dan dikomersialkan Privatisasi dan komersialisasi ruang di kampung telah mengancam ruang terbuka publik yang menjadi tumpuan bernapas dan bersosialisasi warga kampung. Lebih memprihatinkan lagi, telah terjadi tekanan terhadap ruang bermain untuk anak-anak di kampung (Setiawan, 2010).

Kampung Gampingan merupakan salah satu kampung kota yang terletak di bantaran Sungai Winongo Yogyakarta. Kondisi dan permasalahan serupa juga terjadi di Kampung Gampingan, yaitu keterbatasan sarana dan prasarana, lingkungan kampung yang padat, dan minimnya ruang terbuka publik sebagai ruang interaksi akibat beragamnya kepentingan dan aktivitas. Oleh karena itu, Pemerintah Kota Yogyakarta telah menetapkan kampung Gampingan sebagai bagian dari lokasi kawasan kumuh kota Yogyakarta, dimana kampung tersebut menjadi salah satu prioritas penataan kawasan kumuh di kota Yogyakarta. Namun program penataan kampung kota oleh pemerintah maupun pihak-pihak terkait lainnya terkadang hanya terbatas pada penataan lingkungan fisik dan kurang memperhatikan unsur perilaku masyarakat dalam beraktivitas seharihari, khususnya dalam hal interaksi antar warganya. Dengan kondisi tersebut, secara tidak langsung terbentuk interaksi warga yang khas karena terdapat pemanfaatan ruang dengan keterbatasan dimensi maupun seting fisik ruangnya.

Berdasarkan latar belakang tersebut, maka dapat dirumuskan permasalahan sebagai berikut: seting fisik dan bentuk interaksi warga seperti apakah yang terjadi di kampung kota khususnya pada Kampung Gampingan di Kota Yogyakarta. Tujuan dari penulisan ini adalah menghasilkan studi mengenai seting fisik pada suatu tatanan lingkungan kampung Gampingan yang berada di bantaran Sungai Winongo terhadap interaksi warga yang terjadi. Lingkup studi terkait seting fisik ruang interaksi ini difokuskan pada penggalian komponen ruang yang mendukung kegiatan interaksi. Hasil tersebut diharapkan dapat digunakan sebagai referensi dalam melakukan penataan 
Kampung Gampingan sebagai salah satu kawasan kumuh di kota Yogyakarta di masa mendatang yang akomodatif terhadap karakteristik seting ruang interaksi warganya.

\section{Kajian Pustaka}

Sebuah karya arsitektur hakikatnya diciptakan sebagai wadah dari aktivitas (container of activities). Wadah yang dimaksud adalah ruang-ruang yang saling berhubungan dalam satu sistem tata ruang dan berfungsi sebagai tempat berlangsungnya aktivitas tersebut. Gabungan antara beberapa aktivitas yang terdiri dari suatu pola aktivitas tertentu dapat terjadi dalam sebuah seting fisik atau lingkungan. seting fisik yang sama dapat menampung lebih dari satu seting aktivitas pada waktu yang berbeda. Suatu lingkungan mampu menampung beberapa aktivitas tanpa ada perubahan fisik lingkungan sehingga dapat dikatakan terjadi adaptasi lingkungan (Lang, 1987) dalam (Ulum, 2015). Cara hidup dan sistem kegiatan, akan menentukan macam dan wadah bagi kegiatan tersebut. Ruang sendiri dapat dikatakan merupakan fenomena keberadaan manusia dan segala aktivitasnya. Lingkungan terbangun secara tidak langsung merupakan cerminan dari nilai-nilai, kebiasaan, keinginan-keinginan apa yang dianut oleh masyarakatnya (Rapoport, 1977). Ruang juga memungkinkan penggunanya untuk bersosialisasi dan membentuk teritori secara spesifik dalam bentuk bangunan, jalan, zona, penanda atau pembatas ruang (Hillier, 1984).

Wujud ruang sendiri dapat didefinisikan melalui elemen-elemen pembatas, yaitu elemen horisontal dan vertikal. Elemen horisontal dapat berupa lantai (bidang dasar) dan bidang atas, sedangkan elemen vertikal berupa kolom (elemen vertikal linear) dan komposisi bidang vertikal (Ching, 2000). Lingkungan pada sebuah permukiman pada dasarnya dapat dibagi dalam 2 (dua) kelompok, yaitu lingkungan alamiah dan lingkungan buatan, dimana dalam ranah studi arsitektur keduanya sering disebut sebagai seting fisik (Weisman G. D., 1981). Seting fisik terdiri atas pelingup ruang dan properti/elemen pengisi ruang. Pelingkup ruang merupakan aspek fisik yang kasat mata yang bersifat kuantitatif, misalnya lantai, dinding, atau ukuran luas dari sebuah ruang, sedangkan properti/elemen pengisi ruang adalah aspek kualitatif yang dirasakan oleh pengguna ruang seperti suhu atau kesesuaian warna, dan lainnya (Sativa, 2017).

Dalam kampung kota, permasalahan yang kerap hadir pada ruang publik sebagai ruang interaksi warga diantaranya disebabkan oleh faktor ketidakjelasan sifat ruang yang diindikasi dari aktivitas domestik semua hunian yang membaur di luar rumah, sertapenataan ruang yang tidak maksimal karena keterbatasan dimensi ruang sehingga sarana dan prasarana menjadi kurang memadai (Mastutie, 2016).

Dalam penelitian ini, lingkup identifikasi seting fisik difokuskan pada aspek komponen ruang. Studi tentang identifikasi seting fisik pada ruang interaksi warga ini dimaksudkan untuk menggali ragam seting fisik seperti apa yang terbentuk pada kampung bantaran sungai. Ruang kampung yang sebagian besar didominasi oleh bangunan mengakibatkan sempitnya dimensi ruang untuk berinteraksi antar warga. Terbatasnya ruang kampung terkadang justru membuat warganya menjadi "cerdas" untuk beradaptasi dalam menggunakan ruangnya. Dengan mengetahui ragam seting fisik tersebut harapannya hasil penulisan ini dapat digunakan sebagai pertimbangan pada rencana pemerintah kota Yogyakarta dalam melakukan penataan kawasan kumuh di kampung bantaran sungai kota Yogyakarta, khususnya di kampung Gampingan di bantaran Sungai Winongo.

\section{Metode}

Studi tentang identifikasi seting fisik ruang interaksi ini merupakan kajian eksploratif dengan metode observasi lapangan untuk mengumpulkan data. Hasil amatan 
kemudian dianalisis menggunakan kajian literatur tentang komponen ruang pada sebuah seting fisik. Fokus amatan adalah ruang-ruang yang digunakan warga untuk saling berinteraksi. Variabel yang digunakan untuk mengelompokan data dan menganalisis adalah komponen ruang meliputi pelingkup ruang dan elemen pengisi ruang. Variabel pelingkup ruang digunakan karena merupakan aspek dasar dalam pendefinisi ruang secara kuantitatif (kasat mata) sedangakan variabel elemen pengisi ruang sebagai aspek untuk mendefiniskan kualitas ruang secara kualitatif.

Sebagai lokus kajian, dipilih Kampung Gampingan yang terletak di Kelurahan Pakuncen, Kecamatan Wirobrajan, Yogyakarta. Bagian Kampung Gampingan yang dipilih menjadi obyek studi adalah area di RW 10 dan RW 11, yang sebagaian wilayahnya terletak di bantaran Sungai Winongo. Selain itu, Kampung Gampingan dipilih juga karena karakteristiknya sebagai kampung dengan kepadatan tinggi, terletak di bantaran sungai dengan topografi lingkungan yang beragam, tingkat kekumuhan yang tinggi, serta memiliki kondisi sosial-ekonomi yang rata-rata tergolong rendah. Dasar lain pemilihan lokus diperkuat dengan Keputusan Walikota Yogyakarta Nomor 216 Tahun 2016 yang menetapkan bagian tersebut sebagai lokasi kawasan kumuh di kota Yogyakarta, dimana area tersebut menjadi prioritas penataan kawasan kumuh di tahun 2018. Harapannya, hasil penelitian ini dapat menjadi referensi dalam proses penataan kawasan kumuh di Kampung Gampingan sesuai dengan kebiasaan dan kearifan lokal yang sudah ada.

\section{Hasil dan Diskusi}

\subsection{Profil Kampung Gampingan}

Secara administratif, Kampung Gampingan terletak di Kelurahan Pakuncen, Kecamatan Wirobrajan yang mencakup Rukun Warga (RW) 9, 10, dan 11, dimana terdapat 12 Rukun Tetangga (RT). Kondisi perekonomian warga kampung Gampingan termasuk dalam golongan kelas menengah ke bawah. Secara fisik, kampung Gampingan merupakan kampung kota dengan tingkat kepadatan bangunan yang tinggi. Kampung Gampingan juga memiliki topografi yang curam karena berbatasan langsung dengan Sungai Winongo di sisi timur, khususnya pada RW 10 dan 11.

Pemanfaatan lahan yang semakin padat nampak pada daerah yang terletak di bantaran sungai. Permukiman warga tumbuh secara organik dan beberapa menggunakan bantaran sungai. Hampir tidak ditemukan ruang terbuka yang berupa square di kampung ini kecuali pada beberapa halaman rumah warga yang cukup luas serta sebuah fasilitas umum berupa lapangan bulutangkis. Bentuk ruang terbuka yang mendominasi adalah ruang terbuka berupa street yaitu gang-gang sebagai jalur sirkulasi warga. Dengan kondisi tersebut hampir sebagian besar warga memanfaatkan gang sirkulasi tersebut sebagai ruang yang multifungsi untuk mewadahi berbagai aktivitas warga. Hal ini yang menjadi menarik untuk diperhatikan bahwa bagaimana warga menggunakan ruang untuk saling berinteraksi dengan kondisi seting fisik yang khas.

\subsection{Kondisi Seting Fisik Ruang Interaksi Warga di Kampung Gampingan \\ 4.2.1 Sebaran Ruang Interaksi Warga}

Berdasarkan hasil pengamatan, ditemukan 15 (lima belas) ruang yang sering digunakan warga untuk berinteraksi di kampung Gampingan, sebagai berikut: 

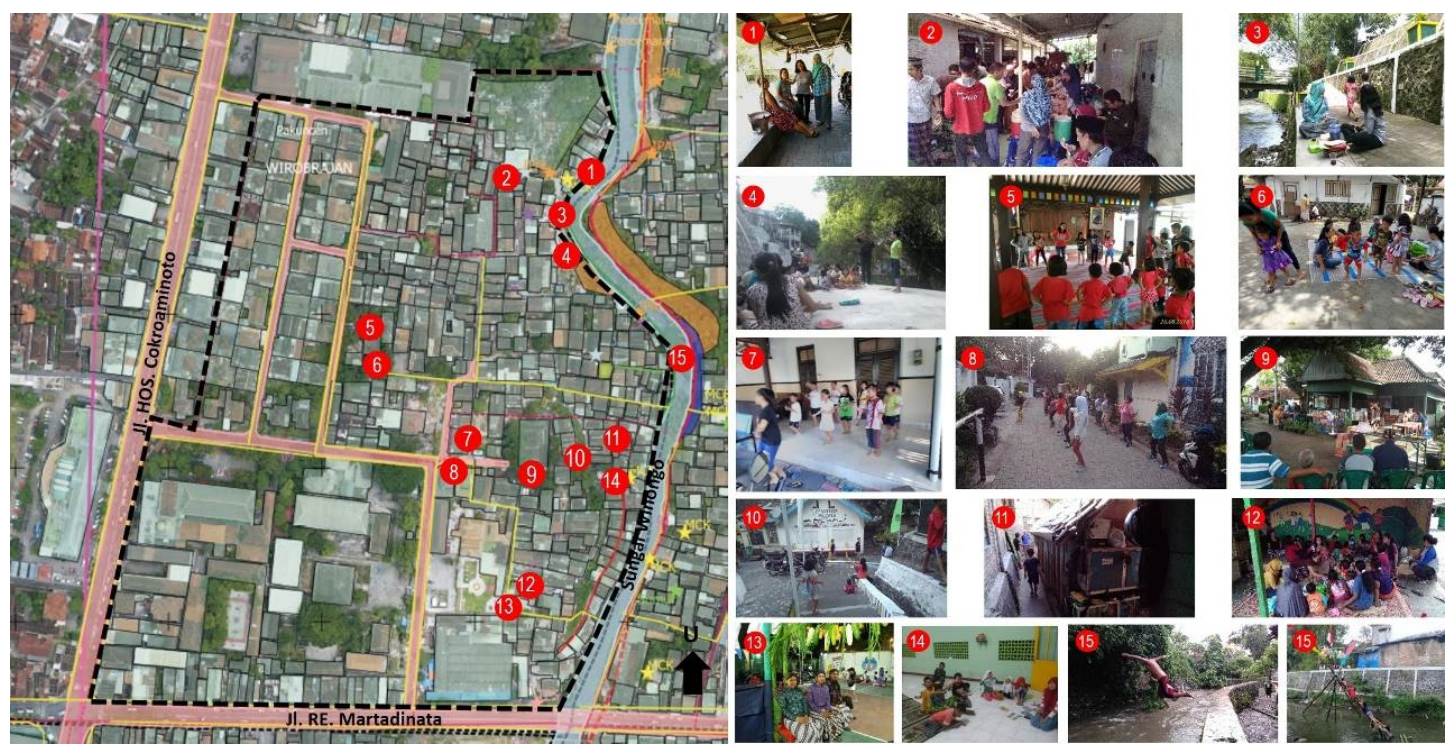

Gambar 1. Letak 14 Ruang Interaksi Warga di Kampung Gampingan

(Sumber: Dokumentasi Edy Rifantono dan Ana Yuliastanti dengan ijin, 2018)

Kelimabelas ruang tersebut dipilih karena masing-masing memiliki karakteristik dan keragaman seting fisik di Kampung Gampingan. Berikut ini akan dijelaskan tentang masing-masing tipe ruang interkasi warga di Kampung Gampingan yang dikelompokkan berdasarkan pelingkup ruang dan elemen pengisi ruang.

\subsubsection{Kondisi Pelingkup Ruang}

Dari kelimabelas ruang yang digunakan warga untuk berinteraksi ditemukan 3 (tiga) tipe ruang interaksi berdasarkan pelingkup ruangnya yaitu ruang terbuka, ruang semi terbuka, dan ruang tertutup. Kriteria dari pengelompokan tersebut adalah bahwa ruang tertutup memiliki elemen pendefinisi ruang yang lengkap (elemen horisontal dan vertikal) dan cenderung solid walaupun dimungkinkan masih terdapat beberapa pengolahan pada pelingkupnya. Ruang semi terbuka adalah ruang yang terdefinisi dari beberapa elemen pendefinsi ruang saja, dimana pelingkup ruangnya merupakan kombinasi unsur tertutup dan terbuka (dapat berupa ruang berbentuk L, U, atau ruang yang terbuka pada salah satu sisinya). Sedangkan ruang terbuka adalah ruang yang hanya memiliki elemen bawah (lantai) dan atau sebagai elemen dinding sebagai elemen pendefinisi ruangnya tanpa penutup atap.

Berdasarkan kondisi pelingkup ruang, nampak bahwa ruang interaksi di Kampung Gampingan didominasi oleh ruang terbuka yaitu sebanyak 8 ruang dari total 15 ruang yang ada. Ruang interaksi tersebut terdiri dari ruang di bantaran sungai (nomor 3, 4, dan 15), ruang di penggal jalan utama kampung (nomor 8 dan 10), ruang di halaman rumah warga (nomor 6 dan 9), dan ruang di lapangan bulutangkis (nomor 13). Sedangkan untuk ruang interaksi yang berupa ruang semi terbuka terletak pada gang sirkulasi kampung antar bangunan (nomor 1, 2, dan 11), bagian depan rumah warga (nomor 5 dan 7), dan balai PAUD (nomor 12). Ruang interaksi warga yang berupa ruang tertutup adalah ruang dalam yang terdapat pada bangunan masjid dan rumah warga (nomor 14). 


\section{Tabel 1. Tipe Ruang Interaksi Warga Berdasarkan Kondisi Pelingkup Ruang}

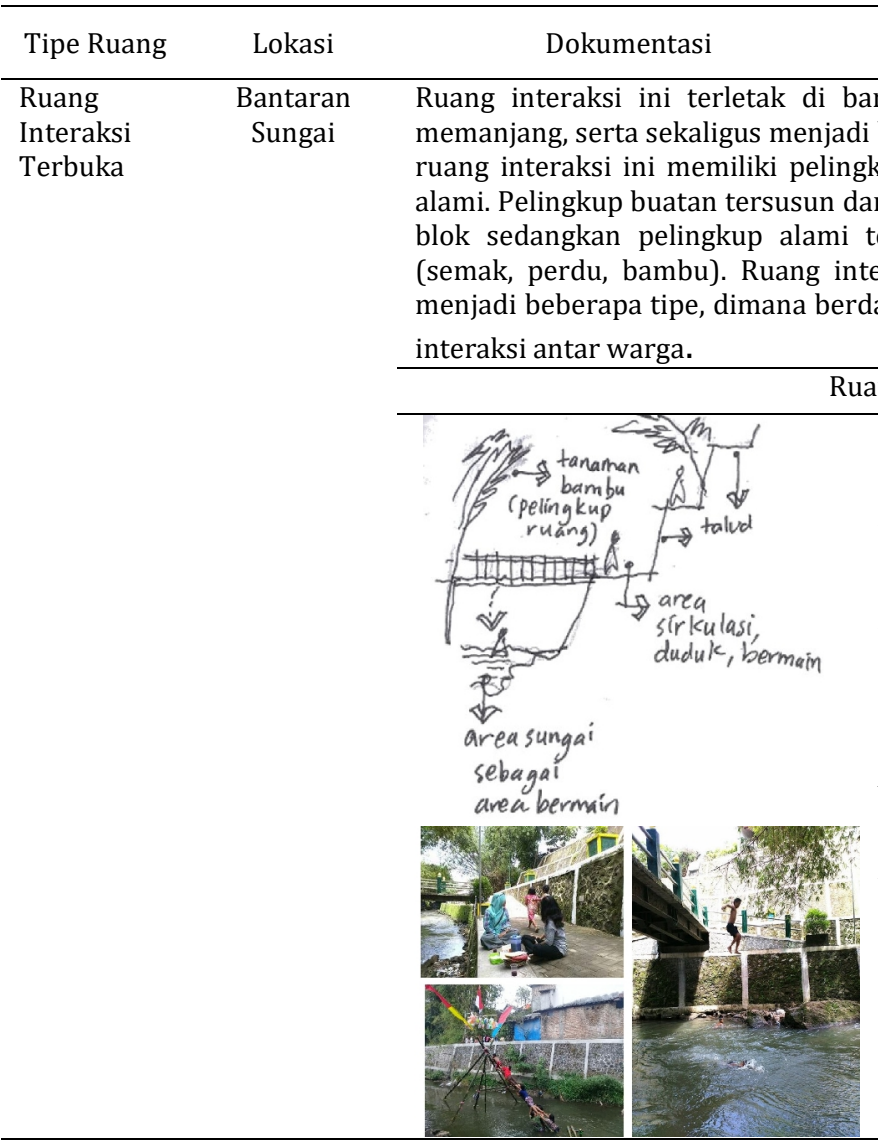

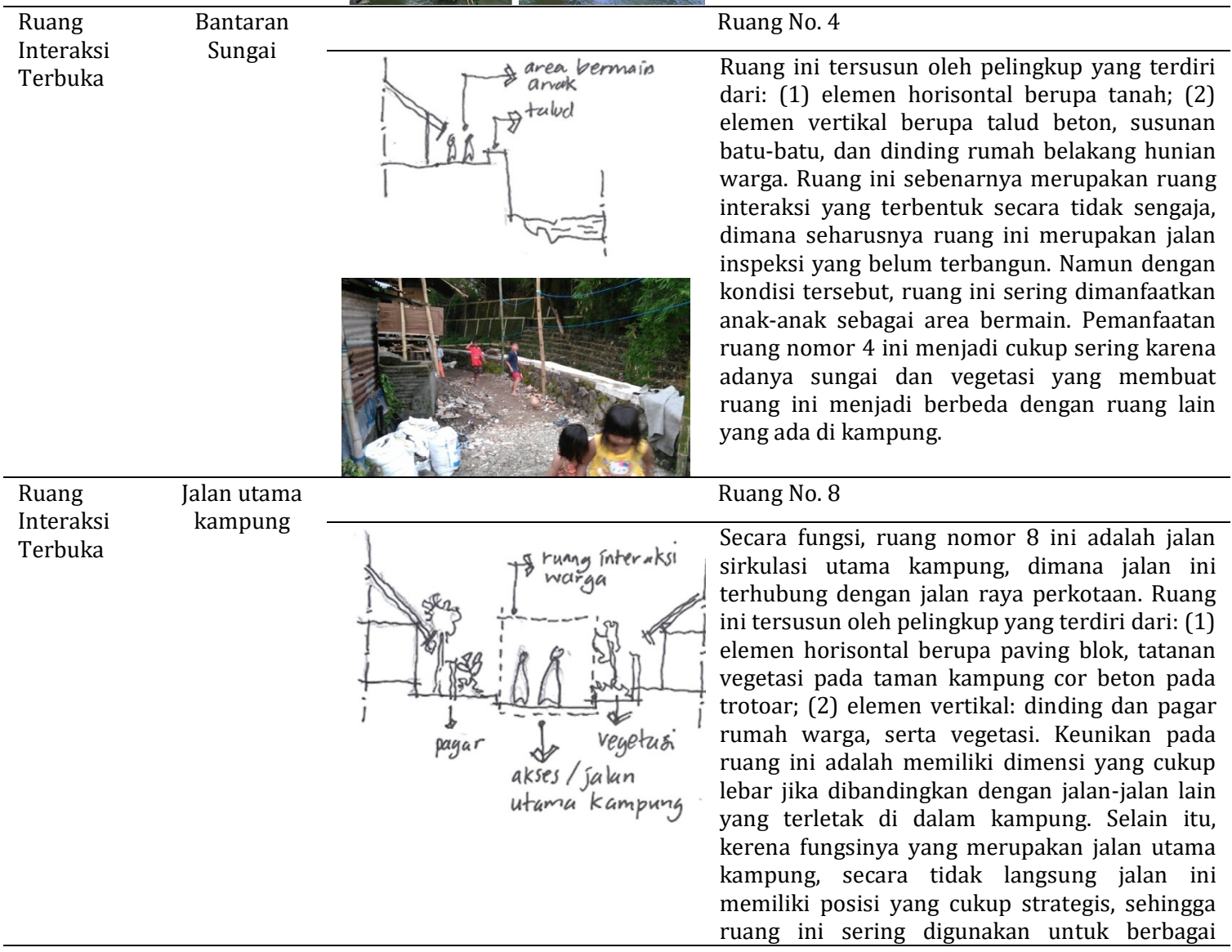




\begin{tabular}{|c|c|c|c|}
\hline Tipe Ruang & Lokasi & Dokumentasi & Keterangan \\
\hline & & & $\begin{array}{l}\text { kegiatan warga dimana beragam interaksi dapat } \\
\text { terjadi disini, seperti kegiatan senam warga, } \\
\text { area bermain anak, pasar murah, dan area } \\
\text { pelatihan/workshop warga. }\end{array}$ \\
\hline Ruang & \multirow{2}{*}{$\begin{array}{l}\text { Jalan utama } \\
\text { kampung }\end{array}$} & & Ruang No. 10 \\
\hline Terbuka & & & $\begin{array}{l}\text { Sama halnya dengan ruang nomor } 8 \text {, ruang } \\
\text { nomor } 10 \text { ini juga berfungsi sebagai ruang } \\
\text { sirkulasi utama kampung. Perbedaan yang } \\
\text { nampak pada ruang ini adalah berupa jalan } \\
\text { sirkulasi menuju area kampung bagian bawah } \\
\text { (ledok). Ruang ini terbentuk dari pelingkup yang } \\
\text { berupa: (1) elemen horisontal: anak tangga dari } \\
\text { semen, talud beton; (2) elemen vertikal: talud } \\
\text { beton, dinding rumah warga, dan vegetasi } \\
\text { peneduh. Komposisi elemen horisontal dan } \\
\text { vertikal membentuk sebuah ruang interaksi } \\
\text { yang khas. Deretan anak tangga sebegai akses } \\
\text { naik dan turun dari kampung atas menuju } \\
\text { bawah memungkinkan warga menggunakannya } \\
\text { sebagai ruang duduk dan ruang bermain anak. } \\
\text { Begitu pula dengan komposisi talud yang } \\
\text { berundak, dimana secara fungsional berperan } \\
\text { sebagai penahan tanah kampung bagian atas } \\
\text { namun sering digunakan anak-anak sebagai } \\
\text { ruang bermain (memanjat, berlari). Komposisi } \\
\text { talud dan anak tanggal memungkinkan ruang } \\
\text { tersebut digunakan sebagai ruang duduk warga } \\
\text { yang cukup luas dan multifungsi, misalnya pada } \\
\text { suatu waktu digunakan sebagai kegiatan } \\
\text { tirakatan dengan model area duduk menerupai } \\
\text { teater. }\end{array}$ \\
\hline \multirow{2}{*}{$\begin{array}{l}\text { Ruang } \\
\text { Interaksi } \\
\text { Terbuka }\end{array}$} & \multirow{2}{*}{$\begin{array}{c}\text { Halaman } \\
\text { rumah warga }\end{array}$} & \multicolumn{2}{|c|}{ Ruang No. 6 dan 9} \\
\hline & & 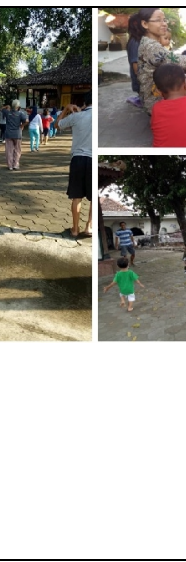 & $\begin{array}{l}\text { Ruang interaksi ini biasanya terdapat pada } \\
\text { rumah warga dengan dimensi yang cukup besar, } \\
\text { dimana masih terdapat halaman sebagai ruang } \\
\text { terbuka. Ruang interaksi ini memiliki pelingkup } \\
\text { berupa: (1) elemen horisontal: perkerasan } \\
\text { paving blok, tanah dengan kontur yang relatif } \\
\text { datar dan luas; elemen vertikal: dinding rumah } \\
\text { warga, vegetasi besar sebagai penaung. Dengan } \\
\text { susunan pelingkup tersebut, keberadaan ruang } \\
\text { ini nampak cukup mencolok di dalam kampung } \\
\text { sehingga memungkinkan digunakan untuk titik } \\
\text { kumpul (meeting point) dan berbagai aktivitas } \\
\text { komunal kampung seperti pelatihan } \\
\text { (hidroponik, dolanan anak, mengolah sampah), } \\
\text { pentas seni, senam, dan berbagai acara } \\
\text { kampung. }\end{array}$ \\
\hline
\end{tabular}




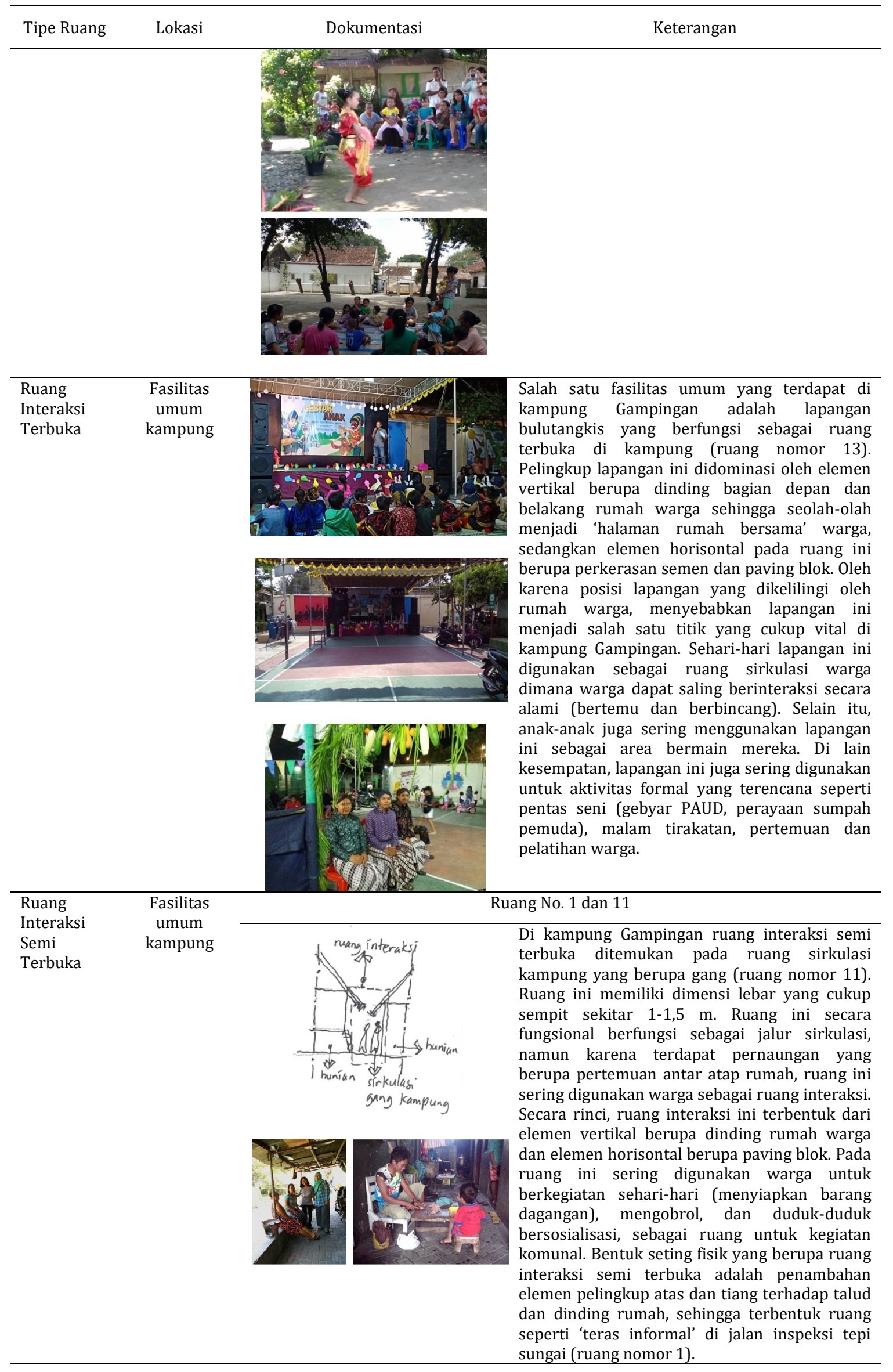




\begin{tabular}{|c|c|c|c|}
\hline Tipe Ruang & Lokasi & Dokumentasi & Keterangan \\
\hline \multirow{2}{*}{$\begin{array}{l}\text { Ruang } \\
\text { Interaksi } \\
\text { Semi } \\
\text { Terbuka }\end{array}$} & \multirow{2}{*}{$\begin{array}{l}\text { Fasilitas } \\
\text { umum } \\
\text { kampung }\end{array}$} & \multicolumn{2}{|c|}{ Ruang No. 5 dan 7} \\
\hline & & & $\begin{array}{l}\text { Ruang interaksi semi terbuka lain terdapat pada } \\
\text { beberapa teras rumah warga (ruang interaksi } \\
\text { nomor } 5 \text { dan } 7 \text { ) dimana ruang ini memiliki } \\
\text { pelingkup berupa dinding yang berlubang } \\
\text { sebagai elemen vertikal dan lantai keramik } \\
\text { rumah sebagai elemen horisontal. Teras rumah } \\
\text { yang biasa digunakan untuk berinteraksi } \\
\text { biasanya terdapat pada rumah warga yang } \\
\text { berukuran besar. Pada kasus nomor } 5 \\
\text { merupakan rumah warga yang memiliki } \\
\text { pendopo, sedangkan kasus nomor } 7 \text { adalah } \\
\text { rumah dengan model limasan kuncung. Kedua } \\
\text { rumah tersebut merupakan area yang sering } \\
\text { digunakan warga untuk ruang berkumpul } \\
\text { melakukan berbagai kegiatan, seperti latihan } \\
\text { menari anak-anak, pelatihan keterampilan } \\
\text { warga, rapat kampung, dan penyuluhan. }\end{array}$ \\
\hline \multirow{2}{*}{$\begin{array}{l}\text { Ruang } \\
\text { Interaksi } \\
\text { Semi } \\
\text { Terbuka }\end{array}$} & \multirow{2}{*}{$\begin{array}{c}\text { Fasilitas } \\
\text { umum } \\
\text { kampung }\end{array}$} & \multicolumn{2}{|r|}{ Ruang No. 12} \\
\hline & & & $\begin{array}{l}\text { Bagian lain dari kampung ini yang dapat } \\
\text { dikategorikan sebagai ruang semi terbuka } \\
\text { adalah bangunan non permanen seperti sanggar } \\
\text { PAUD (ruang nomor 12) dan emper kios } \\
\text { berdagang warga. Balai PAUD sendiri terbentuk } \\
\text { berupa komposisi papan multipleks (elemen } \\
\text { vertikal) dan lantai keramik yang dinaikan } \\
\text { (elemen horisontal) dengan konfigurasi ruang } \\
\text { yang berbentuk "U", dimana bagian yang } \\
\text { terbuka menghadap ke fasilitas publik } \\
\text { (lapangan). Sedangkan kios berdagang warga } \\
\text { terbentuk dari seting fisik berupa tiang bambu } \\
\text { pada keempat sisi (elemen vertikal) dan terpal } \\
\text { (elemen horisontal). Kios ini sering digunakan } \\
\text { anak-anak untuk bermain gadget ketika sedang } \\
\text { tidak digunakan untuk berjualan pemilikinya. }\end{array}$ \\
\hline \multirow{2}{*}{$\begin{array}{l}\text { Ruang } \\
\text { Interaksi } \\
\text { Tertutup }\end{array}$} & \multirow{2}{*}{$\begin{array}{l}\text { Fasilitas } \\
\text { Umum } \\
\text { Kampung }\end{array}$} & \multicolumn{2}{|r|}{ Ruang No. 14} \\
\hline & & & $\begin{array}{l}\text { Ruang interaksi tertutup ditemukan pada ruang } \\
\text { yang memiliki pelingkup ruang yang lengkap, } \\
\text { baik elemen vertikal, horisontal, dan pelingkup } \\
\text { atas yang solid. Ruang ini cenderung mewadahi } \\
\text { kegiatan interaksi yang berlangsung di dalam } \\
\text { ruangan. Sebagai contoh ruang interaks ini } \\
\text { adalah ruang dalam pada rumah warga yang } \\
\text { cukup luas sehingga aktivitas publik (workshop, } \\
\text { rapat, penyuluhan) dapat berlangsung di } \\
\text { dalamnya. Selain itu jenis ruang interaksi } \\
\text { tertutup dapat ditemukan pada ruang dalam } \\
\text { fasilitas umum kampung, seperti ruang dalam } \\
\text { masjid. Kedua contoh tersebut tersusun dari } \\
\text { elemen pendefinisi ruang berupa pasangan batu } \\
\text { bata sebagai elemen vertikal dan lantai keramik } \\
\text { sebagai elemen horisontal. Adanya bukaan } \\
\text { berupa pintu dan jendela memungkinan } \\
\text { terjadinya pergerakan udara dan cahaya alami } \\
\text { sehingga ruang tetapterasa nyaman. }\end{array}$ \\
\hline
\end{tabular}

(Sumber: Analisis Penulis, 2019) 


\subsubsection{Elemen Pengisi Ruang}

Pada bagian ini akan dipaparkan mengenai elemen pengisi ruang dari kelimabelas sampel ruang, dimana elemen pengisi ruang dapat dikelompokkan menjadi elemen tetap (bersifat permanen), elemen tidak semi tetap (relatif mudah dipindah), dan elemen tidak tetap yang selalu bergerak dan dinamis (Rapoport, 1982). Adanya ragam elemen pengisi ruang, tentunya akan berpengharuh terhadap karakteristik ruang. Elemen tetap hampir dapat ditemui pada semua ruang interaksi kampung yang berupa dinding, lantai (keramik, paving blok, cor semen, dan tanah), vegetasi, jembatan, dan talud yang sekaligus merupakan elemen pembentuk ruang. Selain berfungsi sebagai elemen pembentuk ruang, namun elemen tersebut memiliki fungsi tambahan, misalnya talud sebai area duduk, jembatan sebagai area bermain anak di sungai. Hal yang menjadi unik dan menciptakan karakteristik tersendiri pada ruang interaksi adalah kombinasi antara ketiga elemen pengisi tersebut.

\subsubsection{Kombinasi Elemen Tetap dan Elemen Semi Tetap}

Mayoritas ruang interaksi di Kampung Gampingan terbentuk dari elemen pengisi ruang gabungan antara elemen tetap dan tidak tetap. Sebagai contoh, hal ini tampak pada ruang interaksi nomor 5 dan 7 (pendopo dan teras rumah warga), 12 (sanggar PAUD), dan 14 (masjid). Elemen tetap berujud perkerasan lantai, dinding, dan atap, sedangkan elemen tidak tetap berupa perabot yang dapat dipindah (meja, kursi, tikar). Ruang yang cukup luas serta perabot yang mudah dipindahkan menjadikan ruang tersebut sebagai pusat kegiatan komunal warga di Kampung Gampingan. Pada ruang nomor 2 (sirkulasi di depan masjid) dan 11 (gang sirkulasi kampung) hampir memiliki sifat ruang yang sama dengan ruang yang dijelaskan sebelumnya, hal yang membedakan terletak pada dimensi ruangnya. Walaupun memiliki dimensi ruang sempit, ruang ini dapat beradaptasi menjadi ruang interaksi komunal, misalnya pada ruang nomor 2 dapat digunakan sebagai ruang buka bersama saat bulan Ramadhan dengan menambahkan beberapa elemen semi tetap (penambahan kursi, meja).

Ruang interaksi lain yang memiliki kombinasi elemen pengisi tetap dan semi tetap adalah runag nomor 6 dan 9 (halaman rumah warga), 8 dan 10 (sirkulasi utama kampung), dan 13 (lapangan bulu tangkis). Perbedaan dari berberapa ruang sebelumnya adalah adanya elemen tetap yang berupa pohon. Keberadaan pohon membentuk karakteristik tersendiri pada ruang-ruang tersebut. Pohon menghasilkan suasana alami, area teduh, dan memberi kesejukan bagi warga yang sedang berinteraksi. Ruang-ruang ini juga didukung oleh dimensi yang cukup luas, sehingga warga sering memanfaatkan ruang ini untuk berbagai interaksi komunal formal (senam warga, tirakatan, pagelaran seni, penyuluhan) dan informal (bermain anak, momong anak, duduk-duduk).
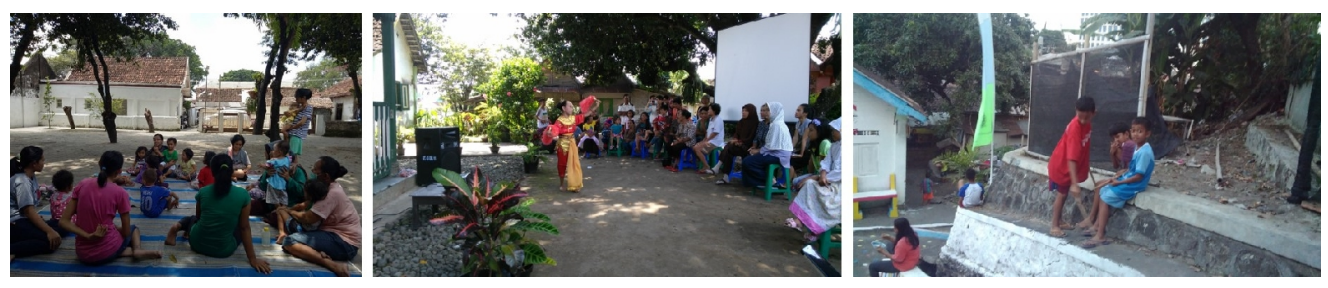

Gambar 2. Ruang Interaksi dengan Kombinasi Elemen Pengisi Tetap dan Semi Tetap (Sumber: Dokumentasi Laurensia Ana dengan ijin, 2018)

\subsubsection{Kombinasi Elemen Tetap dan Elemen Tidak Tetap}

Ruang interaksi dengan kombinasi elemen pengisi tetap dan tidak tetap ini 
mayoritas ditemui pada daerah bantaran Sungai Winongo. Elemen tetap berujud talud, jembatan, dinding rumah, atap non permanen, kelompok pohon bambu, tanah, dan batu di sungai, sedangkan elemen tidak tetap berupa aliran air sungai yang terus bergerak dinamis. Adanya kombinasi kedua elemen tersebut secara tidak langsung membentuk karakter suasana alami pada ruang ini (ruang nomor 1, 3, 4, dan 15) yang tidak ditemukan di tengah-tengah permukiman kampung yang padat. Sebagai contoh pada ruang nomor 3 dimana terdapat kombinasi antara talud tepi sungai, jembatan, pohon bambu, dan aliran sungai sehingga warga sering memafaatkan sebagai ruang santai, momong anak, serta sebagai arena bermain alami anak-anak.
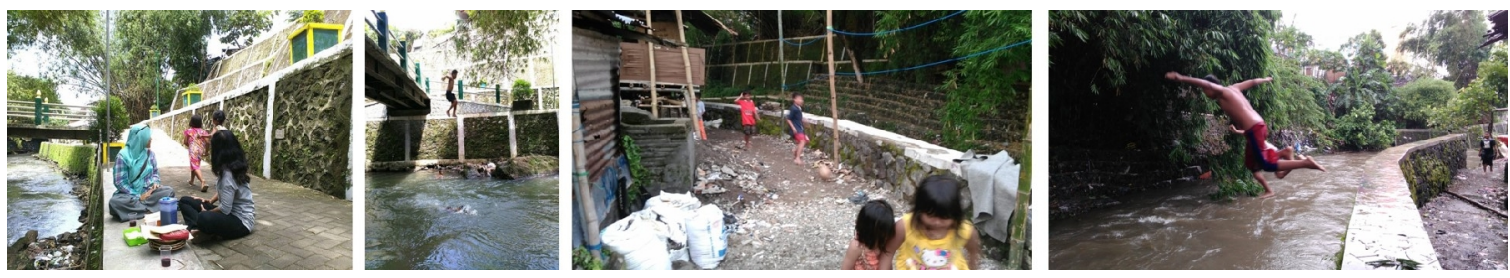

Gambar 3. Ruang Interaksi dengan Kombinasi Elemen Pengisi Tetap dan Tidak Tetap (Sumber: Dokumentasi Laurensia Ana dan Edy Rifantono dengan ijin, 2018)

\subsubsection{Kombinasi Elemen Semi Tetap dan Elemen Tidak Tetap}

Ruang interaksi dengan kombinasi elemen pengisi semi tetap dan tidak tetap ini hanya terdapat pada ruang nomor 15 yang berupa badan sungai. Ruang ini biasanya digunakan secara situasional (tidak tetap). Sebagai contoh, ruang nomor 15 ini dapat digunakan misalnya sebagai arena perlombaan HUT RI. Dengan memanfaatkan aliran air sungai, warga menambahkan bilah-bilah bambu sebagai media perlombaan. Sementara itu, keberadaan elemen tidak tetap berupa ikan-ikan dan pasir di sungai sering menjadi target tangkapan warga untuk memancing ataupun menambang.
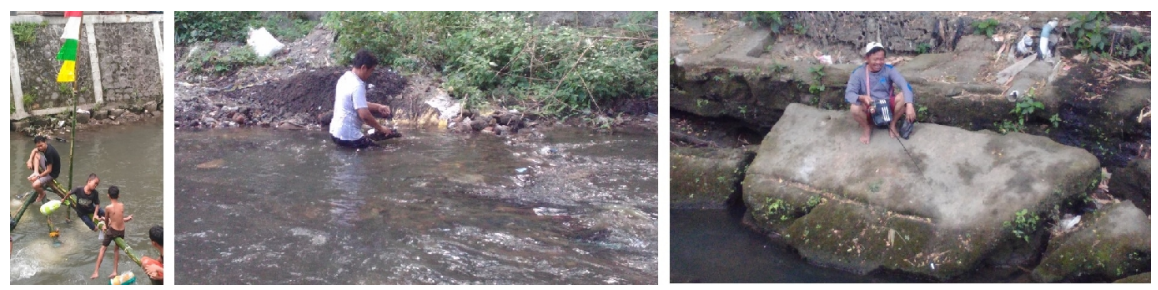

Gambar 4. Ruang Interaksi dengan Kombinasi Elemen Pengisi Semi Tetap dan Elemen Tidak Tetap

(Sumber: Dokumentasi Laurensia Ana dan Edy Rifantono dengan ijin, 2018)

Dari keseluruhan variasi seting fisik ruang interaksi warga di kampung Gampingan yang telah dibahas, maka dapat digambarkan secara singkat melalui tabel distribusi variasi tipe seting fisik ruang interaksi warga berikut.

Tabel 2. Variasi Tipe Seting Fisik Ruang Interaksi Warga di Kampung Gampingan

\begin{tabular}{llllllllllllllllll}
\hline & Kasus Ruang Interaksi & $\mathbf{1}$ & $\mathbf{2}$ & $\mathbf{3}$ & $\mathbf{4}$ & $\mathbf{5}$ & $\mathbf{6}$ & $\mathbf{7}$ & $\mathbf{8}$ & $\mathbf{9}$ & $\mathbf{1 0}$ & $\mathbf{1 1}$ & $\mathbf{1 2}$ & $\mathbf{1 3}$ & $\mathbf{1 4}$ & $\mathbf{1 5}$ & $\Sigma$ \\
\hline $\mathbf{1}$ & $\begin{array}{l}\text { Kondisi Pelingkup } \\
\text { Ruang Interaksi }\end{array}$ & & & & & & & & & & & & & & & & \\
\hline $\mathrm{a}$ & Dominan Terbuka & & & $\mathrm{v}$ & $\mathrm{v}$ & & $\mathrm{v}$ & & $\mathrm{v}$ & $\mathrm{v}$ & $\mathrm{v}$ & & & $\mathrm{v}$ & & $\mathrm{v}$ & 8 \\
\hline $\mathrm{b}$ & $\begin{array}{l}\text { Semi Terbuka } \\
\text { (kombinasi) }\end{array}$ & $\mathrm{v}$ & $\mathrm{v}$ & & & $\mathrm{v}$ & & $\mathrm{v}$ & & & $\mathrm{v}$ & $\mathrm{v}$ & & & & 6 \\
\hline $\mathrm{c}$ & Dominan tertutup & & & & & & & & & & & & $\mathrm{v}$ & & 1 \\
\hline
\end{tabular}




\begin{tabular}{|c|c|c|c|c|c|c|c|c|c|c|c|c|c|c|c|c|c|}
\hline & Kasus Ruang Interaksi & 1 & 2 & 3 & 4 & 5 & 6 & 7 & 8 & 9 & 10 & 11 & 12 & 13 & 14 & 15 & $\Sigma$ \\
\hline 2 & $\begin{array}{l}\text { Kondisi Elemen Pengisi } \\
\text { Ruang }\end{array}$ & & & & & & & & & & & & & & & & \\
\hline a & Dominan Tetap & & & & & & & & & & & & & & & & \\
\hline $\mathrm{b}$ & $\begin{array}{l}\text { Kombinasi Tetap \& Semi } \\
\text { Tetap }\end{array}$ & & $\mathrm{v}$ & & & $\mathrm{v}$ & $\mathrm{v}$ & $\mathrm{v}$ & $\mathrm{v}$ & $\mathrm{v}$ & $\mathrm{v}$ & $\mathrm{v}$ & $\mathrm{v}$ & $\mathrm{v}$ & $\mathrm{v}$ & & 11 \\
\hline c & $\begin{array}{l}\text { Kombinasi Tetap \& Tidak } \\
\text { Tetap }\end{array}$ & $\mathrm{v}$ & & $\mathrm{v}$ & $\mathrm{v}$ & & & & & & & & & & & & 3 \\
\hline d & $\begin{array}{l}\text { Kombinasi Semi Tetap } \\
\text { dan Tidak Tetap }\end{array}$ & & & & & & & & & & & & & & & $\mathrm{v}$ & 1 \\
\hline 3 & Karakter ruang & & & & & & & & & & & & & & & & \\
\hline a & Alami & & & & & & & & & & & & & & & $\mathrm{v}$ & 1 \\
\hline b & Buatan & & $\mathrm{v}$ & & & $\mathrm{v}$ & & $\mathrm{v}$ & & & & $\mathrm{v}$ & $\mathrm{v}$ & & $\mathrm{v}$ & & 6 \\
\hline c & Kombinasi & $\mathrm{v}$ & & $\mathrm{v}$ & $\mathrm{v}$ & & $\mathrm{v}$ & & $\mathrm{v}$ & $\mathrm{v}$ & $\mathrm{v}$ & & & $\mathrm{v}$ & & & 8 \\
\hline
\end{tabular}

Hasil dari tabel di atas dapat dideskripsikan bahwa esensi sebuah ruang dalam lingkungan terbangun dapat tercapai secara fungsional dengan berbagai bentuk definisi teritori ruang. Hal ini dapat terlihat bahwa ruang dengan seting fisik terbuka dengan elemen pengisi kombinasi tetap dan semi tetap serta karakter ruang kombinasi alamibuatan memungkinkan tercipta sebuah wadah untuk beragam aktivitas interaksi antar warga. Ruang-ruang tersebut dapat berwujud bangunan itu sendiri, ruang jalan, ruang di antara bangunan, maupun zona-zona atau penanda yang tercipta dari beberapa elemen ruang luar (vegetasi, talud, sungai) (Hillier, 1984). Selain itu, hasil dari tabel di atas juga menunjukkan bahwa kepadatan dan keterbatasan lahan pada kampung kota dalam hal ini Kampung Gampingan yang juga terletak di bantaran Sungai Winongo memberikan dampak bagi penghuninya untuk beraktivitas dan berperilaku. Semua ruang yang ada harus dioptimalkan pemanfaatannya berupa kombinasi pelingkup, elemen pengisi, dan karakter ruang untuk dapat digunakan sebagai ruang berinteraksi. Ruang-ruang sirkulasi kampung, bantaran sungai yang sempit dan terbatas dimanfaatkan untuk beragam aktivitas yang dapat mencerminkan nilai-nilai, kebiasaan, keinginan-keinginan apa yang dianut oleh masyarakat Kampung Gampingan (Rapoport, 1977).

\section{Simpulan}

Berdasarkan analisis yang telah dilakukan maka ditemukan kategori ruang interaksi warga berdasarkan komponen seting fisik ruang, yakni ruang interaksi terbuka, semi terbuka, dan tertutup serta elemen pengisi ruang tetap, semi tetap, tidak tetap, maupun kombinasi. Dari kategori tersebut dapat terlihat bahwa seting fisik ruang kampung yang digunakan warga sebagai ruang interaksi didominasi oleh ruang dengan pelingkup terbuka dengan elemen pengisi ruang kombinasi tetap dan semi tetap yang terwujud dalam berbagai skala dan ukuran ruang. Keterbatasan ruang kampung membentuk keunikan tersendiri bagi warga dalam menggunakan ruangnya untuk berinteraksi. Dapat terlihat dari Gambar 5 bahwa semakin beragam pelingkup, elemen pengisi, dan karakter seting fisik ruang maka semakin beragam pula kemungkinan jenis interaksi yang dapat terjadi. Sebagai contoh: (1) Ruang interaksi di tengah kampung dengan kepadatan bangunan sedang: merupakan ruang interaksi komunal cederung bersifat formal dikarenakan dimensi ruang yang cukup luas dan tata massa bangunan yang lebih teratur; (2) Ruang interaksi di tengah kampung dengan kontur yang lebih rendah dengan kepadatan bangunan sedang: merupakan ruang interaksi informal (pemanfaatan kontur sebagai area bermain) dan formal pemanfaatan kontur sebagai ruang komunal yang terencana; (3) Ruang interaksi di tengah kampung dengan kontur 
yang lebih rendah serta kepadatan bangunan tinggi: merupakan ruang interaksi informal antar penghuni rumah; (4) Ruang interaksi di bantaran sungai dengan kepadatan bangunan tinggi: merupakan ruang interaksi informal yang cenderung bebas namun akomodatif terhadap berbagai keperluan dikarenakan elemen pengisi ruang yang beragam.
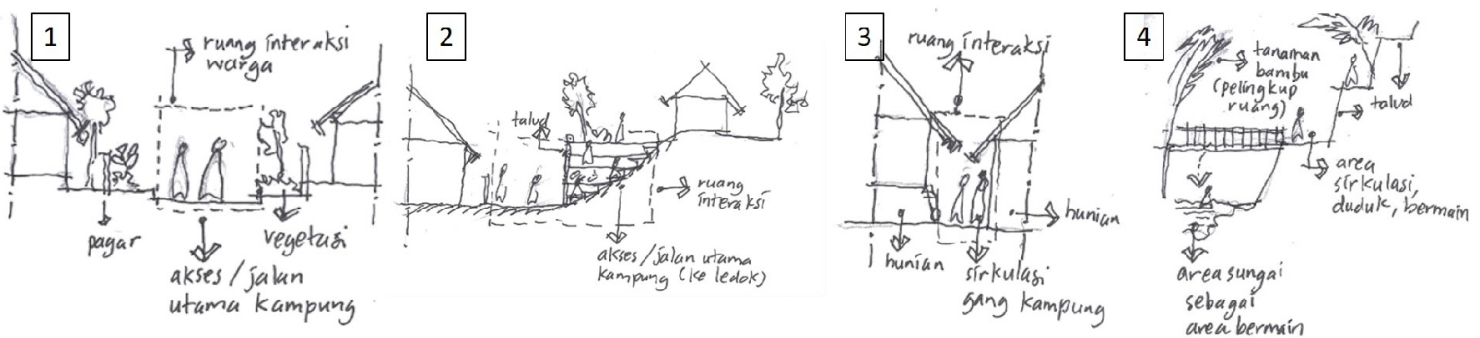

Gambar 5. Keunikan Seting Fisik Ruang Interaksi di Kampung Gampingan

(Sumber: Analisis Penulis, 2019)

Kegiatan interaksi dapat berlangsung secara adaptif dengan melakukan perubahan seting pelingkup maupun elemen pengisi ruang sesuai kebutuhan. Sebagai contoh, pada ruang jalan sirkulasi utama atupun gang kampung dapat digunakan sebagai ruang bermain anak, ruang bersantai, maupun ruang kegiatan komunal yang bersifat lebih formal melalui beberapa cara modifikasi seting fisik ruangnya. Ruang tersebut cenderung lebih kondusif dan adaptif untuk berinteraksi jika terbentuk dari kombinasi pelingkup ruang serta elemen pengisi ruang. Hal-hal seperti ini yang seharusnya diakomodasi bagi setiap pemangku kepentingan dalam setiap rencana penataan kampung bantaran sungai di masa depan. Hasil dari kajian ini diharapkan dapat menjadi salah satu referensi dalam melakukan penataan Kampung Gampingan sebagai salah satu bagian kawasan kumuh di kota Yogyakarta atau kampung yang memiliki karakter serupa di masa mendatang yang akomodatif terhadap karakteristik seting ruang interaksi warganya.

\section{Daftar Pustaka}

Ching, F. D. (2000). Arsitektur: Bentuk, Ruang dan Tatanan. Jakarta: Erlangga.

Haryadi. (1995). Arsitektur Lingkungan dan Perilaku. Proyek Pengembangan Pusat Studi Lingkungan, Direktorat Jenderal Perguruan Tinggi, Departemen Pendidikan dan Kebudayaan RI.

Hillier, B. a. (1984). The Social Logic of Space. Cambridge: Cambridge University.

Kusyala, D. (2008). Prinsip Pengembangan Kampung Kota berdasarkan Pola Berhuni Warga. Bandung: Master Theses Architecture ITB.

Lang, J. (1987). Creating Architectural Theory. New York: Van Nostrand Reinhold Company.

Mastutie, F., Supardjo, S., Prijadi, R. (2016). Ruang Publik pada Permukiman Padat Kota di Kawasan. Temu Ilmiah IPLBI (pp. 197-202). Malang: Ikatan Peneliti Lingkungan Binaan.

Rapoport, A. (1977). Human Aspect of Urban Form, Towards a Man-Environment Approach to Urban Form and Design. Oxford: Pergamon Press.

Rapoport, A. (1982). The Meaning of the Bulit Environment. India: SAGE Publications.

Sativa, B. S. (2017). Variasi Seting Fisik Ruang Interaksi Anak di Kampung Padat Kota Yogyakarta. Inersia, 167-177.

Setiawan, B. (2010). Kampung Kota dan Kota Kampung: Tantangan Perencanaan Kota di Indonesia. Yogyakarta: Universitas Gadjah Mada. 
Sharma, B. (2012). Adjustment and emotional maturity among first year college student. Pakistan Journal of Social and Clinical Psychology 10 (2), 32-34.

Sunaryo, R. G. (2009). Perubahan Setting Ruang dan Pola Aktivitas Publik di Ruang Terbuka Kampus UGM. Seminar Nasional Riset Arsitektur dan Perencanaan (SERAP) 1 Humanisme, Arsitektur, dan Perencanaan (pp. 175-182). Yogyakarta: Universitas Gadjah Mada .

Tamariska, S.R., Ekomadyo, A. S. (2017). 'Place Making' Ruang Interaksi Sosial Kampung Kota Studi Kasus: Koridor Jalan Tubagus Ismail Bawah Bandung. Seminar Kearifan Lokal dan Lingkungan Binaan (pp. 1-17). Medan: Departemen Arsitektur Fakultas Teknik Universitas Sumatera Utara.

Ulum, S.M., Mustikawati, T., Ridjal, A.M. (2015). Koridor Kampung Kota sebagai Ruang Komunikasi Informal. Jurnal Mahasiswa Jurusan Arsitektur Universitas Brawijaya, 7 (1). Retrieved from http://arsitektur.studentjournal.ub.ac.id/index.php/jma/article/view/90/87

Weisman, G. D. (1981 ). Man Environment Model. Journal of Man-Environment Relations, Vol. 1 No. 2.

Yuliastuti, N. (November 2011). Pengaruh Jalan Lingkungan sebagai Ruang Interaksi Sosial. Tata Loka Volume 13 Nomor 4, 190-196. 